\title{
Role of Patrapinda Sweda and Matrabasti in management of Katishoola (Low back pain)- A case study
}

\author{
Case Report
}

\section{Rajkumar Mishra1 $^{*}$, Sanjukta Sengupta² ${ }^{\text {Jayashankar Mund }}{ }^{3}$}

\author{
1. Ph.D Scholar, 3. Principal and Professor of Samhita Siddhanta, \\ Mandsaur Institute of Ayurvedic Education and Research, BRNCOP campus, Mandsaur University, Mandsaur. \\ 2. Professor, Department of Rognidan, \\ S.S.N Ayurveda College and Research Institute, Paikmal, Bargarh, Odisha.
}

\begin{abstract}
Low back pain (LBP) is the most common chronic musculoskeletal disorder. It has symptoms like pain, swelling, stiffness or limited range of motion and these symptoms lie very close to the entity Katigraha\&Katishoola in Ayurveda which is coming under Vatavyadhi(diseases of Nervous system and musculoskeletal system). The Contemporary management has little effect on the disease. It is an important clinical, social, economic and public health problem affecting the population indiscriminately. It is a disorder with many possible aetiologies, occurring in many groups of the population, and with many definitions. The prevalence of LBP in Indian population has been found to vary between $6.2 \%$ (in general population) to $92 \%$ (in construction workers). This problem supposedly has a favourable natural history, although it can markedly disable, and has challenged the health care providers. Understanding the role of different medical systems in the management of backache, it is important for the costeffective management of the disease. Ayurveda treatment modality, exercise, regimen may result in low backache recovery. Here in this article, the diagnostic and treatment aspects are discussed and applied critically using Ayurvedic therapy.
\end{abstract}

Key Words: Low back pain, Katishoola, Patrapinda sweda, Matrabasti, Panchakarma.

\section{Introduction}

Kati Shoola (LBP) is a disease which is mainly caused by vitiation of VataDosha. Some ancient texts also describe Kati Shoola as a symptom of some disorders such as KatiGraha, TrikaGraha, PrushtaGraha, KatiVayu, TrikaShoola, PrushtaShoola, VatajaShoola, TrikaVedana, and GrudrasiVata. And it is mainly caused due to Vata Prokopaahara (diets), Vihara (regimen) and Abhighata (infliction of trauma) [1].

It can be correlate with Low back pain. According to ICD 10, classification of low back pain comes under 2021 ICD-10-CM Diagnosis Code M54.5 criteria.Clinically it is defined as Acute or chronic pain in the lumbar or sacral regions, which may be associated with musculo-ligamentous sprains and strains; intervertebral disc displacement; and other conditions. [2] Sometimes pain in the low back, thighs, which radiates into the buttocks, muscle spasms, leg pain, or weakness, tight hamstring muscles, and irregular gait can be seen.

\section{* Corresponding Author:}

\section{Rajkumar Mishra}

Ph.D Scholar,

Mandsaur Institute of Ayurveda Education and

Research, BRNCOP campus,

Near Krishiupaj Mandi, Mandsaur. India

Email Id: rajkmishra1986@gmail.com
Many treatment regimens are described classically to treat patients suffering from Katishoola. like snehana,swedana,Basti etc. Acharya Charaka has explained, 13 types of swedana in Swedadhyaya .PatrapindaSweda is a form of swedana which is included under the category of Pindasweda. Application of the heat and there by inducing perspiration by using heated pack of special herbal leaves like eranda,arka,nirgundi etc. is known as Patrapinda sweda. Following Abhyanga(Oleation) procedure may be subjected to swedana procedure by the method of Patrapinda sweda. As the oil is applied before the swedana procedure, this belongs to the category of snigdha- ushnasweda.[3]

As we understood this pathogenesis in broad spectrum due to above etiological factors there is disturbance in Katipradesha which is the Vatasthana occurs due to asthidhatuvaishamyata. As we know that Bastichikitsa is main therapy of Vatadosha also known as Ardhachikitsa.It is directly act on Vatasthana which regulates the Apanvayu[4]. So, to breakdown this pathogenesis ( Sampraptivightana), In the present study, we have selected panchakarma therapy i.e.,snehana(oleation), swedana external application of Patrapinda sweda along with internal administration of Matrabasti in management of Katishoola.

\section{Case report}

A 49-year-old woman, who attended the Outdoor Patients, department of Panchakarma, R.K 
Shyam Baboo Prasad et.al., Role of Patrapinda Sweda and Matrabasti in management of Katishoola (Low back pain)

University Ayurvedic college Hospital, Rajkot, for treatment of her lower back pain., who presented with complaints of Pain, swelling in low back since lyears. Sometime it worsens after daily routine activity. On examination, mild Swelling, Tenderness were present in lumbar region and showing painful movements with SLR 60 Degree. She had no history of trauma and her symptoms were increased gradually.

Motor and sensory functions were normal in right and left legs and both deep and superficial reflexes were also normal. All details of the patient including present history, past history, treatment history, dietary habits, lifestyle, and addictions were recorded before the treatment. Necessary examinations and X-rays in lumbo-sacral region were done and finding was recorded. Visual analogue Scale was assessed for pain and WOMAC Scale was assessed for pain, Stiffness and physical function of the Low back.Patient was kept on a normal diet without any specific restrictions and was advised not to lift any weight. The patient was treated with Ayurvedic treatment regimens for 14 days. Details are as below.

\section{General examination}

General built was Normal, Blood pressure was 130/90 mmHg, Respiratory rate 18-20 /Min, BMI 31 kg/ $\mathrm{m}^{2}$.

\section{Table 1: Examination}

\begin{tabular}{|c|c|c|}
\hline & & \\
\hline & Pain & $\begin{array}{l}\text { Pain radiates bilaterally up to the } \\
\text { thigh only. }\end{array}$ \\
\hline 2 & Stiffness & Movement restricted due to stiffness. \\
\hline 3 & $\begin{array}{l}\text { Numbness/ } \\
\text { Paraesthesia }\end{array}$ & Mild Numbness in both leg \\
\hline 4 & SLR Test & 60 degree \\
\hline 5 & Gait & Normal \\
\hline 6 & Sensory loss & No sensory loss \\
\hline 7 & Weakness & $\begin{array}{l}\text { Moderate weakness on movement of } \\
\text { thigh, Dorsi flexion of foot and } \\
\text { plantar flexion was normal }\end{array}$ \\
\hline 8 & Reflex & $\begin{array}{l}\text { Knee, Hamstring, Ankle Reflexes } \\
\text { normal }\end{array}$ \\
\hline & of $\mathbf{n}$ & \\
\hline 1 & Flexion & $60^{0}$ \\
\hline 2 & Extension & $35^{0}$ \\
\hline 3 & Lateral Flexion & $20^{0}$ \\
\hline
\end{tabular}

Table 2. Systemic Examination

\begin{tabular}{|c|c|}
\hline $\begin{array}{l}\text { Central } \\
\text { nervous } \\
\text { System }\end{array}$ & Normal \\
\hline $\begin{array}{l}\text { Respiratory } \\
\text { System }\end{array}$ & Chest Clear, No added sound \\
\hline $\begin{array}{l}\text { Cardiovascular } \\
\text { System }\end{array}$ & $\begin{array}{l}\text { Trachea centrally placed, no dilated or } \\
\text { engorged veins, no scars or other visible } \\
\text { pulsation, Apical impulse felt, S1 S2 sound } \\
\text { heard, no Thrill-Murmur. }\end{array}$ \\
\hline $\begin{array}{l}\text { G.I. } \\
\text { Examination }\end{array}$ & $\begin{array}{l}\text { P/A Inspection: No abnormality seen } \\
\text { Palpation: Soft abdomen, Abdomino- } \\
\text { thoracic movement is Normal, No bulging } \\
\text { during expiration, No Hernia, No } \\
\text { splenomegaly/hepatomegaly. }\end{array}$ \\
\hline
\end{tabular}

\section{AshtavidhaPariksha( eight-fold examination)}

Nadi ( pulse) was 86 beats/min, Mala ( $\sim$ stool) was Asamyak ( constipated, 1 time a day, unsatisfactory bowel habit), Mutra ( urine) was samyak, Jeeva ( tongue) was Niram ( uncoated), Shabda( $\sim$ speech) was Spashta $(\sim \mathrm{clear})$, Sparsha $(\sim$ Touch $)$ was anushnasheeta( normal), Druka ( eyes) was Prakruta ( no pallor and no Icterus), Akruti ( body structure) was uttama( obesity with high body weight).

\section{Dashavidha pariksha( Ten-fold examination)}

Prakruti was Vatakaphaj, Sara was Madhyam, Samhanana was Madhyam, Pramana was Madhyam, Satmya was sarvaras, Satva was Madhyama, Aharashakti was hina, jaranashakti was hina, Vyayamshakti was Madhyama, vaya was Madhyamavastha.

\section{Nidanapanchaka( diagnostic quintet)}

- Nidana: Due to the intake of vatakara ahara, vihara,the vatakara nidanas like ativyayaama, stressfull activities, etc. leads to vitiation of Vatadosha, which is confined to its own location.

- Purvarupa: The occurrence of symptoms at minimal severity was the Purvarupa for vatavyadhi. So, here in the context of katishoola the occasional occurrence of back pain, stiffness was the Purvarupa.[5]

- Rupa: The excited vata spreads to the katipradesha i.e., the snayu, peshi, asthi of katipradesha occasionally causing pain, stiffness at the katipradesha and restricted range of movement of kati.[6]

- Samprapti: The vitiated doshas get residence at the afflicted places in the body. The various Vatakara Nidana specially those giving on due strain to the katipradesha produces srotovigunata in the channels. The vitiated vatadosha undergoes localization at the site of kha-vaigunya. The dosha vitiates the dushya (asthi, snayu, peshi, majja) by confining itself to the katipradesha.Theresfore symptoms of pain and stiffness are occurring in a mild form distinctive of poorvaroopa of vatavyadhii.e.katishoola. [7]

- Vyaktaavastha:The dosha vitiates the dushya (asthi, snayu, peshi, majja) by confining itself to the katipradesha and manifest as a disease. This stage is marked by thepresence of pain, stiffness and restricted range of movement.[8]

- Bhedavastha: As the negligence continues the disease proceeds into more severe forms due to extensive dhatukshaya. It finally attains asadhyata in this stage. This stage can make the condition worse by manifestation of degenerative changes in the dushyaas (asthi) which are irreversible.[9] 
International Journal of Ayurvedic Medicine, Vol 12 (3), 700-704

\section{Table 3: Samprapti Ghatakas of Katishoola}

Dosha

Dushya

VātaVyanaApana (Vrudhi)

\begin{tabular}{|l|l|} 
& UpadhatuSnayu \\
\hline Udbhavasthana & Pakwashaya \\
\hline Vyaktasthana & Kati \\
\hline Sancharasthana & Sharira \\
\hline Srotas & Asthivaha \\
\hline
\end{tabular}

\section{Investigations}

Haemoglobin was $14.2 \%$, White blood count was $9500 \mathrm{Cells} / \mathrm{Cu} \mathrm{mm}$, ESR was $15-\mathrm{mm}$ in $1 \mathrm{hr}$, Blood urea nitrogen was $9.89 \mathrm{mg} / \mathrm{dl}$, Serum Creatinine was $0.82 \mathrm{mg} / \mathrm{dl}$, uric acid was $6.11 \mathrm{mg} / \mathrm{dl}$, and calcium was $9.67 \mathrm{mg} / \mathrm{dl}$. Other blood investigations like RA, ASO, CRP were done to rule out other disease conditions.

\section{X-Ray lumbo sacral spine AP-LAT View}

Degenerative changes in lumber vertebra, osteophytes developed in L3, L4, L5vertebrae.

Diagnosis based on the sign and symptom, VAS score, WOMAC scale, X-ray and blood investigation.

\section{Materials and Methods}

Snehana and swedana are the main line of treatment in vatavyadhi, and in katishoola vata is the prime factor for pain. So treatment planned was Snehana (oleation)in the form of Abhayangha(massage) externally and internally Matrabasti (Oil enema). And Patrapindasweda as swedana was planned for the case. Assessment of condition of the patient before and after treatment was done based on Subjective parameters (pain, stiffness, swelling) and Objective parameter (Visual analogue scale and WOMAC )scale for pain and physical activity grading, to evaluate efficacy of the treatment. Based on the assessment parameters, significant improvement was seen in the subjective symptoms and pain scale after the completion of a schedule of 14 days of treatment and follow up after 1 month. The physical activity grading also improved significantly.

\section{Treatment Protocol}

Snehana and Swedana are the main treatment planned for this case. Snehana as Abhyanga with Ksheerabala taila, swedana with Patrapinda sweda for 7 days. Abhyantara Snehana MatrabastiAdministration of Medicated oil through the rectal route. In this case study, ksheerabala taila was used for Matrabasti for 7 days.Treatment done for a total period of 14 days. The ingredients of above-mentioned medications are given below in the tables.

\section{Table 4: Interventional Schedule}

\begin{tabular}{|c|c|c|c|}
\hline Days & Treatment & $\begin{array}{l}\text { Dura } \\
\text { tions }\end{array}$ & Dose \& Drugs \\
\hline $\begin{array}{l}\text { 1 }{ }^{\text {ST }} \text { Day } \\
\text { to-7days }\end{array}$ & $\begin{array}{l}\text { Abhyanga and } \\
\text { Mrudusweda }\end{array}$ & $\begin{array}{c}45 \\
\min \end{array}$ & $\begin{array}{c}\text { Ksheerabala Taila } \\
100 \mathrm{ml}\end{array}$ \\
\hline $\begin{array}{l}\text { 1ST Day } \\
\text { to-7days }\end{array}$ & $\begin{array}{l}\text { Patrapinda } \\
\text { sweda }\end{array}$ & $\begin{array}{c}45 \\
\min \end{array}$ & $\begin{array}{l}\text { Vatahara leaves like } \\
\text { Eranda, Nirgundi, } \\
\text { Arka } \\
\text { Ksheerabala taila }\end{array}$ \\
\hline $\begin{array}{l}8^{\text {th }} \text { Day } \\
\text { to- } 14^{\text {th }} \\
\text { days }\end{array}$ & $\begin{array}{l}\text { Abhyanga and } \\
\text { mrudu sweda } \\
\text { followed by } \\
\text { Matrabasti }\end{array}$ & $1 \mathrm{Hr}$ & $\begin{array}{l}\text { Ksheerabala taila } \\
\quad 72 \mathrm{ml}\end{array}$ \\
\hline
\end{tabular}

Table 5: Ingredients of KsheerabalaTaila

\begin{tabular}{|c|c|c|}
\hline Sl.no. & Drug & Botanical Name \\
\hline 1 & Balamulam & Sida cordifolia \\
\hline 2 & Tilataila & Sesamum indicum \\
\hline 3 & Ksheeram & \\
\hline
\end{tabular}

Oil was prepared with the above ingredients for external and internal application

Subjective and Objective assessment was done before treatment and after treatment.

Assessment Criteria

Table 6: Subjective criteria

\begin{tabular}{|c|c|c|}
\hline Sl.no & Lakshana & Grading \\
\hline 1 & Pain & $0=$ None \\
\hline & Morning stiffness & $2=$ Moderate \\
\hline 3 & Swelling & $4=$ Extremely \\
\hline
\end{tabular}

Objective criteria

Table 7: VAS Scale Grading

\begin{tabular}{|c|c|c|}
\hline Range of Pain & Vas score & Grade \\
\hline No pain & 0 & 0 \\
\hline Mild Pain & $1-3$ & 1 \\
\hline Moderate Pain & $4-6$ & 2 \\
\hline Severe Pain & $7-9$ & 3 \\
\hline Worst pain & 10 & 4 \\
\hline
\end{tabular}

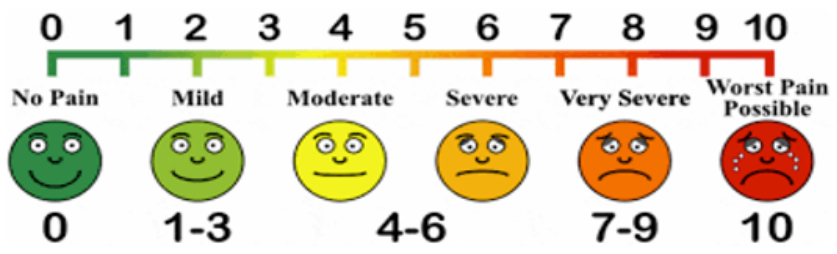

Table 8: WOMAC Scale Grading

\begin{tabular}{|c|c|c|}
\hline WOMAC question & WOMAC score & Grade \\
\hline None & 0 & 0 \\
\hline Mild & $1-24$ & 1 \\
\hline Moderate & $25-48$ & 2 \\
\hline Severe & $49-72$ & 3 \\
\hline Extreme & $73-96$ & 4 \\
\hline
\end{tabular}

\section{Observation and result}

Visual analogue scale to assess severity of pain Before and After Treatment 
Shyam Baboo Prasad et.al., Role of Patrapinda Sweda and Matrabasti in management of Katishoola (Low back pain)

\section{Before Treatment}

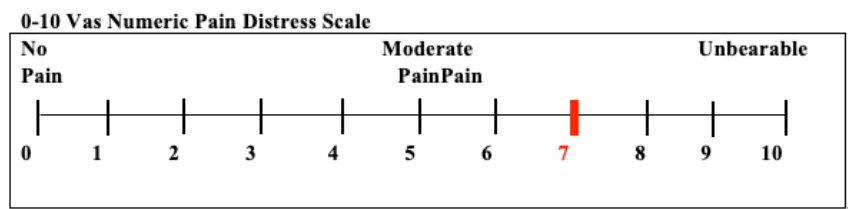

\section{After Treatment - Vas scale}

Visual analogue scale (consolidated) represented in line diagram shows improvement

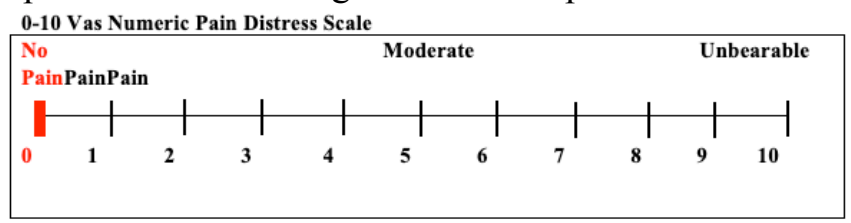

Sum and average of WOMAC grading before and after treatment are calculated and compared.

Table 9: WOMAC Scale (Western Ontario and Mc Master Universities) shows drastic improvement

\begin{tabular}{|c|c|c|c|c|}
\hline S.No & Symptoms & Activity & BT & BT \\
\hline \multirow{5}{*}{1} & \multirow{5}{*}{ Pain } & Walking & $\mathbf{0}$ & $\mathbf{0}$ \\
\hline & & Stair Climbing & 2 & $\mathbf{0}$ \\
\hline & & Nocturnal & 2 & $\mathbf{0}$ \\
\hline & & Rest & $\mathbf{0}$ & $\mathbf{0}$ \\
\hline & & Weight bearing & 2 & $\mathbf{0}$ \\
\hline \multirow[b]{2}{*}{2} & \multirow[b]{2}{*}{ Stiffness } & Morning stiffness & 2 & $\mathbf{0}$ \\
\hline & & $\begin{array}{l}\text { Stiffness } \\
\text { occurring later in } \\
\text { the day }\end{array}$ & $\mathbf{0}$ & $\mathbf{0}$ \\
\hline \multirow{18}{*}{3} & \multirow{17}{*}{$\begin{array}{l}\text { Physical } \\
\text { functions }\end{array}$} & Descending Stairs & 1 & $\mathbf{0}$ \\
\hline & & Ascending Stairs & 3 & 1 \\
\hline & & $\begin{array}{l}\text { Rising from } \\
\text { sitting }\end{array}$ & 2 & $\mathbf{0}$ \\
\hline & & Standing & 1 & $\mathbf{0}$ \\
\hline & & Bending to floor & 3 & 1 \\
\hline & & $\begin{array}{l}\text { Walking on flat } \\
\text { surface }\end{array}$ & $\mathbf{0}$ & $\mathbf{0}$ \\
\hline & & $\begin{array}{l}\text { Getting in or out } \\
\text { of car }\end{array}$ & $\mathbf{0}$ & $\mathbf{0}$ \\
\hline & & Going shopping & 3 & 1 \\
\hline & & Putting on socks & $\mathbf{0}$ & $\mathbf{0}$ \\
\hline & & Lying in bed & $\mathbf{0}$ & $\mathbf{0}$ \\
\hline & & Taking of socks & $\mathbf{0}$ & $\mathbf{0}$ \\
\hline & & Rising from bed & 2 & $\mathbf{0}$ \\
\hline & & $\begin{array}{l}\text { Getting in/out of } \\
\text { bath }\end{array}$ & 0 & $\mathbf{0}$ \\
\hline & & Sitting & $\mathbf{1}$ & $\mathbf{0}$ \\
\hline & & $\begin{array}{l}\text { Getting in/out of } \\
\text { Toilet }\end{array}$ & 1 & $\mathbf{0}$ \\
\hline & & $\begin{array}{l}\text { Heavy domestic } \\
\text { duties }\end{array}$ & 3 & 1 \\
\hline & & $\begin{array}{l}\text { Light domestic } \\
\text { duties }\end{array}$ & 2 & $\mathbf{0}$ \\
\hline & Total Score & Out of 96 & 30 & 4 \\
\hline
\end{tabular}

Table 10 Overall effect of the therapy

\begin{tabular}{|c|l|c|c|}
\hline Sno. & \multicolumn{1}{|c|}{ Lakshana } & $\begin{array}{c}\text { Before } \\
\text { Treatment }\end{array}$ & $\begin{array}{c}\text { After } \\
\text { Treatment }\end{array}$ \\
\hline $\mathbf{1}$ & Pain & 3 & 1 \\
\hline $\mathbf{2}$ & Morning stiffness & 2 & 0 \\
\hline $\mathbf{3}$ & Swelling & 1 & 0 \\
\hline $\mathbf{4}$ & Pain VAS SCALE & 2 & 0 \\
\hline $\mathbf{5}$ & WOMAC Scale & 2 & 0 \\
\hline
\end{tabular}

BT -Before treatment, AT -After treatment -WOMAC Scale
Follow up period - 1month

Treatment was administered as per the prescribed schedule.

\section{Discussion}

As Vata is the most important factor causing Katishoola(Low back pain) and Snehana-Swedana is the first line of treatment of Vatadosha.And as in this case degenerative changes were observed.The Abhyanga carried out before the swedana are likely to correct the imbalances of Vatadosha.[11] In addition to this, the sudation procedure helps in rectifying the morbid doshaas well.ThePatrapinda sweda is very much efficacious in such clinical conditions.[12] It Alleviates the pain and swelling.So,Abhyanga with the Ksheerbala Tail, Patrapinda Sweda followed by Matrabasti with ksheerbala Tail was effective and markedly improved in the sign and symptoms of Katishoola(Low back pain).

\section{Conclusion}

Abhyantara and bahyasnehana and swedanaPatrapindasweda is highly effective in Low back pain. This case showed significant improvement in symptomsimmediatelyafterthetreatment. After follow up no reoccurrence of symptom was noted.This indicates that Snehana and swedana both have a long way of action in the effective management in Lowback pain. But a longer duration study with a large sample size must be done to get more accurate conclusions. On the basis of this single case study, it can be concluded that panchakarma procedures like patrapinda sweda and Matrabasti had been effective in the management of the Low back pain.

\section{References}

1. SushrutaSamhita (Purvardha), edited by Ambikadatta Shastri, Published by Chaukhambha Sanskrit Sangsthan, Varanasi Reprint Edition: 20, Su.Ni. 1/11-20.

2. https://www.icd10data.com /ICD10CM/Codes/ M00-M99/M50-M54/M54-/M54.5

3. Cakradatta of Shri Cakrapani data, Edited and translated by Dr.P.V.Sharma, Vatavyadhi Adhikara 22/83,Edition 2007, Chaukhamba publishers, Varanasi, pg193

4. Sharma R, Textbook of Ayurvediya panchakarma chikitsa vigyan, edition 2nd 2019: Jagdish Sanskrit pustkalaya, page.no. 235-238.

5. Ashtanghradaya of Vagbhata with the commentaries, Sarvangasundara of Arundatta and Ayurvedarasayana of Hemadri, edited by pt. Harisadasivasastriparadakara, Chaukhambha Sanskrit sansthan Varanasi, Reprint 2011, nidana sthana chapter15 Vatavyadhinidanshloka 5,6 p.n.530, 531.

6. Charaka samhita of Agnivesa elaborated by Charaka and Drdhabala with The Ayurvedadipika commentary by Chakrapanidatta, edited by Vaidya Jadavaji Trikamji acharya, Chaukhamba Surbharati 
Prakashan, Varanasi, edition 2008, chikitsa sthana chapter28 vata vyadhi cikitsa, shloka 18,19 p.n.617.

7. Ashtanghradaya of Vagbhata with the commentaries, Sarvangasundara of Arunadatta and Ayurveda rasayana of Hemadri, edited by pt. Harisadasivasastriparadakara, Chaukhambha Sanskrit sansthan Varanasi, Reprint 2011, nidana sthana chapter 15 Vatavyadhi nidan shloka 7,8 p.n.532, 533 .

8. Charaka samhita of Agnivesa elaborated by Charaka and Drdhabala with the Ayurvedadipika commentary by Chakrapanidatta, edited by Vaidya Jadavaji Trikamji acharya, Chaukhamba Surbharatiprakashan, Varanasi, edition 2008, nidana sthana chapter 1 Jwaranidana, shloka 8 p.n.194.

9. Charakasamhita of Agnivesa elaborated by Charaka and Drdhabala with the Ayurvedadipika commentary by Chakrapanidatta, edited by Vaidya Jadavaji Trikamji acharya, Chaukhamba surbharati prakashan, Varanasi, edition 2008, chikitsa sthana chapter28 Vatavyadhicikitsa,shloka 19 p.n.617.

10. Charaka samhita of Agnivesa elaborated by Charaka and Drdhabala with the Ayurvedadipika commentary by Chakrapanidatta, edited by vaidya Jadavaji Trikamji acharya, chaukhamba surbharati prakashan, Varanasi, edition 2008, chikitsa sthana chapter 28, Vatavyadhicikitsa, shloka 23 p.n.617.

11. Acharya Vagbhata, Astanga Hridayam, elaborated by Vagbhata, with joint commentaries Ayurveda Rasayana by Hemadri and Sarvanga sundara by Arunadatta, Pt. Hari Sadashiva Sastri Paradakara, Chikitsasthana, Vatavyadhi adhyaya, 21/4,Reedition: 2012, Chaukambha Sanskrit Sansthan, Varanasi, pg 722

12. Charaka Samhita, Vidyotani Hindi Commentary by Kasinath Sastri $7^{\text {th }}$ edition sutra stana, chapter 14, verse 39 Varanasi, Chaukhamba Sanskrit Samstan 2002. 